\title{
Effectiveness of selected alternative methods of airway management by the nursing staff
}

Skuteczność wybranych metod alternatywnego udrażniania dróg oddechowych przez personel pielęgniarski

\section{Ewelina Iwanicka1 ๑ ${ }^{\oplus}$, Paweł Więch ${ }^{2}$, Izabela Sałacińska² ${ }^{\oplus}$, Joanna Przybek-Mita² (0)}

'Student Scientific Club of Emergency Medicine, College of Medical Sciences, University of Rzeszów, Rzeszów/ Studenckie Koło Naukowe Medycyny w Stanach Nagłych, Kolegium Nauk Medycznych, Uniwersytet Rzeszowski 2Institute of Health Sciences, College of Medical Sciences, University of Rzeszów, Rzeszów/ Instytut Nauk o Zdrowiu, Kolegium Nauk Medycznych, Uniwersytet Rzeszowski

CORRESPONDING AUTHOR/AUTOR DO KORESPONDENCJ:

Ewelina Iwanicka

College of Medical Sciences, University of Rzeszów

Al. Kopisto 2a, 35-310 Rzeszów

e-mail: eweliwan@interia.eu

\section{STRESZCZENIE}

\section{SKUTECZNOŚC WYBRANYCH METOD ALTERNATYWNEGO UDRAŻNIANIA DRÓG ODDECHOWYCH PRZEZ PERSONEL}

\section{PIELEGNIARSK}

Cel pracy. Celem badania była ocena skuteczności wybranych metod alternatywnego udrażniania dróg oddechowych przez personel pielęgniarski.

Materiał i metodyka. Prospektywne, pilotażowe badanie obserwacyjne przeprowadzone na grupie 51 pielęgniarek będących w trakcie szkolenia specjalizacyjnego lub posiadających specjalizację. Każda pielęgniarka udrażniała drogi oddechowe za pomocą maski krtaniowej (LMA - Laryngeal Mask) oraz rurki krtaniowej (LT-D - Laryngeal Tube) na trenażerze BT-CSIE a następnie przeprowadzała minutową wentylację z użyciem worka samorozprężalnego, zgodnie z posiadaną wiedzą i umiejętnościami. Uzyskane parametry (czas, nacisk na siekacze, odchylenie głowy, jakość wentylacji) rejestrowano przy użyciu dedykowanego tabletu. Analiza statystyczna została wykonana za pomocą pakietu IBMSPSS Statistics 20.

Wyniki. Nie zaobserwowano statystycznie istotnych różnić między próbą udrożnia dróg oddechowych za pomocą LMA a LT-D. Wykazano wyższą skuteczność udrożnienia dróg oddechowych LMA w pierwszej próbie oraz średnią objętość oddechową podczas wentylacji w stosunku do LT-D (LMA 547,84 ml vs.LT-D 522,63 ml). Ponadto odnotowano znaczącą różnicę nacisku na siekacze (LMA 6,82 N vs. LT-D 4,12 N).

Wnioski. Skuteczność założenia LMA i LT-D oceniono na wysokim poziomie, przy jednoczesnym braku istotnych różnic pomiędzy nimi. Zmienne: wiek, staż pracy, poziom wykształcenia oraz rodzaj specjalizacji, nie różnicowały istotnie uzyskanych wyników.

Aim. The aim of the study was to assess the effectiveness of selected methods of alternative airway management by nursing staff. Material and methods. A prospective, pilot observational study was conducted on a group of 51 nurses undergoing specialization training or with specialty. Each nurse managed the airway with a laryngeal mask (LMA-Laryngeal Mask) and a laryngeal tube (LT-D-Laryngeal Tube) on a BT-CSIE trainer, and then carried out one minute ventilation using a bag valve mask, according to possessed knowledge and skills. The obtained parameters (time, pressure on the incisors, head tilt, ventilation quality) were recorded using a dedicated tablet. Statistical analysis was performed using the IBMSPSS Statistics 20 package.

Results. No statistically significant differences were observed between the trials to open the airway using LMA and LT-D. Higher efficiency of LMA airway opening was demonstrated in the first trial and the average tidal volume during ventilation in relation to LT-D (LMA 547.84ml vs. LT-D 522.63ml). In addition, there was a significant difference in pressure on the incisors (LMA 6.82N vs. LT-D $4.12 \mathrm{~N})$.

Conclusions. The effectiveness of LMA and LT-D insertion was assessed at a high level, with no significant differences between them. Variables: age, seniority, education level and type of specialization did not significantly differentiate the results obtained. 
Effectiveness of selected alternative methods of airway management by the nursing staff

\section{INTRODUCTION}

Sudden cardiac arrest (SCA) is a major cause of death in hospital and out-of-hospital settings both among children and adults [1]. The key task of medical staff is to recognize life emergency early and initiate Basic Life Support (BLS) and Advanced Life Support (ALS) procedures, including effective instrumental airway management $[2,3]$. World literature has described endotracheal intubation as the gold standard in effective airway management $[4,5]$. Numerous factors disrupt the performance of this procedure in a relatively short time, alternative tools for airway management, such as the Laryngeal Mask Airway (LMA) and the Laryngeal Tube (LT), are increasingly used. The results of current studies included in the guidelines of the European Resuscitation Council (ERC) confirm the effectiveness of their application in SCA [3,6,7]. Pursuant to the law in force in Poland, nurses can open the airways using LT and LMA after completing a specialist course in cardiopulmonary resuscitation (CPR), or after specialization, in particular if they meet the criteria of a system nurse [8]. The analysis of the publications contained in medical databases (Medline, Ebsco, Polish Medical Bibliography) revealed no studies on the effectiveness of opening the airways with alternatives in the group of nurses, taking into account management time and its effectiveness.

\section{AIM}

The aim of the study was to assess the effectiveness of selected methods of alternative airway management by nursing staff.

\section{MATERIALS AND METHOD}

The study was approved by the Bioethics Committee at the University of Rzeszów (Resolution No. 2018/03/13e). It were carried out on March 17-24, 2018, after obtaining prior consent to participate in the study. The measurements were carried out at the Postgraduate Education Center of Nurses and Midwives in Rzeszów and at the Center for Medical and Natural Sciences Research and Innovation, University of Rzeszów. The study group of nurses participated in study during the last two weeks of specialization in emergency nursing, anaesthesiological nursing or qualification course of anesthetic training. The nurses were recruited through the dissemination of an invitation to the research by the Postgraduate Education Center of Nurses and Midwives in Rzeszów where the specialization and course were implemented.

The study included a group of 51 nurses with the right to practice. Sampling was deliberate. The following inclusion criteria were adopted: informed consent to participate in the study, health status enabling tests to be carried out using selected research tools, having a specialized CPR course, having specialized training or being in the course of such training. All nurses participating in the study met the criteria of a system nurse $[8,9,10]$. The characteristics of the study group is shown in Table 1 .

\section{Tab. 1. The characteristics of the study group}

\begin{tabular}{|l|c|}
\hline \multirow{2}{*}{ Age } & \multicolumn{1}{|c|}{ Study group ( $\mathbf{n}=\mathbf{5 1}$ ) } \\
\cline { 2 - 2 } 25 (frequency) \\
\hline $31-40$ yrs & 23 \\
\hline Above 40 yrs & 12 \\
\hline Work seniority & 16 \\
\hline Up to 5 yrs & \multicolumn{2}{|c|}{} \\
\hline 6-10 yrs & 21 \\
\hline $11-20$ yrs & 13 \\
\hline Above 20 yrs & 8 \\
\hline Education & 9 \\
\hline secondary & \multicolumn{2}{|c|}{} \\
\hline higher & 10 \\
\hline Specialization & 41 \\
\hline Surgical & \multicolumn{2}{|c|}{} \\
\hline Cardiac care & 2 \\
\hline In course of anesthetic training & 2 \\
\hline In course of emergency medicine training & 16 \\
\hline
\end{tabular}

Before the study, a short, preliminary training on how to use an evaluation trainer was carried out (a head model for invasive airway opening - BT-CSIE, BT Inc., 2015). After the introduction, the task was presented, the purpose of which was to insert the laryngeal tube (LT-D, size 5, VBM Laryngeal Tube) and silicone laryngeal mask (LMA, size 5, Outline), according to one's knowledge and skills. The order of inserting LT-D and LMA was independent. Then, the nurses carried out minute ventilation using a bag valve mask (capacity approx. $1700 \mathrm{ml}$, Ambu, Poland). An amount of $500-600 \mathrm{ml}$ was adopted as the norm for normal tidal volume. The correct head tilt was assumed as an indicator of the beginning of the task, while LMA or LT-D sealing and the first breath during ventilation were adopted as the end. The correctness of task performance was analyzed using a dedicated check-list. Each of the nurses examined immediately after the LMA insertion test performed an attempt to insert LT-D. In the absence of the correct insertion of an alternative in the first trial, the tested subjects had the opportunity to try again. The evaluation of the effectiveness of selected methods was performed by the authors of the study (nurse practitioner) working in a pair but evaluating independently.

A research questionnaire was prepared for the purpose of organizing the collected data. The questionnaire consisted of: sociodemographic data, a table for assessing the insertion of alternative methods of airway management and a Check-list.

The obtained results were analyzed using tests assessing the differences between the studied groups. Due to the presence of a dependent variable on the quantitative scale, an independent variable on the qualitative scale, and the lack of normality of distribution (assessed by the Shapiro-Wilk test), non-parametric analyzes were used: Mann-Whitney U test (for 2 trials) and Kruskal Wallis test (for more than 2 trials). The level of statistical significance was 
adopted at $\mathrm{p}<0.05$. Calculations were carried out using the IBMSPSS Statistics 20 package.

\section{RESULTS}

Comparing the obtained results of selected parameters regarding the LMA insertion procedure, it was found that the LMA mask was more effective in relation to LT-D in the first trial. The insertion time for LMA averaged 30.22 s (SD 10.44), while LT-D $32.26 \mathrm{~s}$ (SD 9.44). The analysis of ventilation performed by the examined nurses showed a higher tidal volume after opening the airway with the LMA mask - average $547.84 \mathrm{ml}$ (SD 117.9) in relation to ventilation using LT-D, which was performed by 43 nurses - average $522.63 \mathrm{ml}$ (SD 96.58). The average maximum pressure on the incisors when inserting the LMA was 6.82 $\pm 8.148 \mathrm{~N}$ and ranged from $0 \mathrm{~N}$ to $16 \mathrm{~N}$, in the case of LT-D the average maximum pressure was $4.12 \pm 5.48 \mathrm{~N}$ and ranged from $0 \mathrm{~N}$ to $16 \mathrm{~N}$.

The degree of head tilt when inserting the LMA was $59.10 \pm 13.503$ and ranged from 5 degrees to 69 degrees. In the case of LT-D, most of the examined people cleared their airways by tilting the head back, where the average was $61.00 \pm 9.04$ and ranged from 0 degrees to 70 degrees. The amount of ventilation within a minute of LMA was $16.51 \pm 5.471$ and ranged from 11 to 31 . In turn, LT-D average ventilation per minute was $15.20 \pm 4.712$ and ranged from 4 to 27 . No statistically significant differences were observed between the subjects methods (Tab. 2).

Tab. 2. Comparison of LMA and LT-D insertions during the first trial

\begin{tabular}{|l|c|c|c|}
\hline \multirow{2}{*}{ Parameter } & \multicolumn{2}{|c|}{ Study group } & \multirow{2}{*}{ p value } \\
\cline { 2 - 3 } & LMA (I trial) & LT-D (I trial) & \\
\hline Time (s) & $30.22 \pm 10.44$ & $32.36 \pm 9.44$ & 0.457 \\
\hline Pressure (N) & $6.82 \pm 8.15$ & $4.12 \pm 5.48$ & 0.080 \\
\hline Head tilt & $59.10 \pm 13.50$ & $61.00 \pm 9.04$ & 0.942 \\
\hline Tidal volume (ml) & $547.84 \pm 117.90$ & $522.63 \pm 96.58$ & 0.175 \\
\hline Ventilation & $16.51 \pm 5.47$ & $15.20 \pm 4.71$ & 0.366 \\
\hline
\end{tabular}

Mann Whitney $\mathrm{U}$ test ; Time - time required to insert the alternative in seconds;

Pressure - maximum pressure on the incisors measured in $\mathrm{N}$; Head tilt - the degree of head inclination in the axis;

Tidal volume - mean respiratory volume of rescue breaths per minute measured in milliliters;

Ventilation - amount of ventilation per minute

Selected variables such as age, seniority, level of education, type of specialization did not significantly differentiate the procedure of the airway management with LMA and LT-D $(\mathrm{p}<0.05)$.

\section{DISCUSSION}

The present study evaluated the effectiveness of alternative airway clearing using the laryngeal mask and laryngeal tube in simulated conditions, performed by the system nurses. Parameters determining the effectiveness of the procedure in relation to selected variables were assessed. Our study showed the effectiveness of LMA as a tool for clearing the airways. In the first trial, the laryngeal mask was inserted by all the nurses, while $64.7 \%$ of the respondents performed the task correctly. The above results are consistent with the observations of other authors. In the studies of Van Zundert et al., anesthesiologists inserted selected alternatives during surgery on a group of 150 patients. The effectiveness of the procedure for inserting the LMA was found at 98-99\% [11]. Ockner et al. examining a group of 50 patients undergoing anesthesia, whose anesthesia team randomly managed the airways with LT-D and LMA, obtained results determining the effectiveness of the laryngeal mask at $71-90 \%$ [12].

According to ERC guidelines, both intubation and airway management with LMA and LT-D should be performed within 30 seconds [13]. In our study, the average insertion time was $30.22 \mathrm{~s}$ for LMA and $32.36 \mathrm{~s}$ for LT-D respectively. The study by Matterlein $\mathrm{T}$ et al. conducted in a group of 22 anesthesiologists showed that all trials to insert LMA were successful and the procedure time was in the range of 13-17 s [14,15]. Ventilation after the airway managements with LMA turned out to be higher in relation to LT-D, as much as $47.1 \%$ of the subjects ventilated with a volume within the range of 500-600 $\mathrm{ml}$, and the average number of breaths introduced during $60 \mathrm{~s}$ was on average $15 /$ minute.

Laryngeal tube LT, just like LMA is a tool for alternative airway management. In our study ventilation with LT-D was effective in $60 \%$. In turn, in studies by Ketta et al. in patients with SCA, ventilation with LT was effective in $80 \%$ of cases [16].

In our study, 43 subjects tested the laryngeal tube in the first trial. The duration of the procedure in the first trial was within 14-59 s, while in the second trial 14-35 s. As many as $43.1 \%$ of the respondents after inserting LT ventilated in the range of $500-600 \mathrm{ml}$, while the average number of breaths made was 14/minute. No studies of other authors regarding the quality of ventilation using LT were found.

Comparing the effectiveness of using LMA and LT-D in the author's study, no statistical significance was noted. Nonetheless, clearing the airways with LMA enabled higher tidal volumes to be achieved with higher pressure on the incisors.

Numerous reports indicate that the most appropriate method of clearing the airways is endotracheal intubation. However, it is associated with many complications and should be performed by trained and practicing medical staff. People who do not have such skills or are not able to intubate should use alternative methods such as LT-D and LMA due to the ease and speed of insertion and conducting effective ventilation using a bag-valve mask. Systematic training of nurses and all medical personnel is also important, including the possibility of practical implementation of the procedure in emergency situations

\section{CONCLUSIONS}

The effectiveness of inserting LMA and LT-D among nurses was assessed at a high level, with no significant differences between the alternatives. Age, seniority, education level and type of specialization did not significantly differentiate the results obtained. 


\section{Skuteczność wybranych metod alternatywnego udrażniania dróg oddechowych przez personel pielęgniarski}

\section{WPROWADZENIE}

Nagłe zatrzymanie krążenia (NZK) w warunkach szpitalnych, jak i pozaszpitalnych stanowi główną przyczynę zgonów, zarówno wśród dzieci jak i osób dorosłych [1]. Kluczowym zadaniem personelu medycznego jest wczesne rozpoznanie stanu zagrożenia życia oraz rozpoczęcie podstawowych (BLS) i zaawansowanych zabiegów resuscytacyjnych (ALS), w tym skuteczne przyrządowe udrożnienie dróg oddechowych [2,3]. Literatura światowa od wielu lat wskazuje intubację dotchawiczą jako złoty standard w skutecznym zabezpieczaniu dróg oddechowych $[4,5]$. Ze względu na liczne czynniki ograniczające wykonanie tej procedury w relatywnie krótkim czasie, coraz częściej stosuje się alternatywne narzędzia służące do udrażniania dróg oddechowych, takie jak maska krtaniowa (Laryngeal Mask Airway - LMA) oraz rurka krtaniowa (Laryngeal Tube - LT). Dotychczasowe wyniki badań zawarte w wytycznych Europejskiej Rady Resuscytacji (European Resuscitation Council - ERC) potwierdzają skuteczność ich zastosowania w sytuacji NZK [3,6,7]. Zgodnie $\mathrm{z}$ prawem obowiązującym w Polsce, pielęgniarka może udrażniać drogi oddechowe $\mathrm{z}$ wykorzystaniem LT oraz LMA po odbyciu kursu specjalistycznego z zakresu resuscytacji krążeniowo-oddechowej (RKO), bądź po specjalizacji, w szczególności jeśli spełnia kryteria pielęgniarki systemu [8]. Analizując publikacje zawarte w bazach medycznych (Medline, Ebsco, Polska Bibliografia Lekarska) nie znaleziono badań poddających analizę skuteczność zakładania alternatyw w grupie pielęgniarek, uwzględniając czas założenia i skuteczność.

\section{CEL PRACY}

Celem badania była ocena skuteczności wybranych metod alternatywnego udrażniania dróg oddechowych przez personel pielęgniarski.

\section{MATERIAŁ I METODYKA}

Badanie zostało pozytywnie zaopiniowane przez Komisję Bioetyczną przy Uniwersytecie Rzeszowskim (Nr 2018/03/13e). Przeprowadzono je w dniach 17-24 marca 2018, po uprzednim wyrażeniu zgody na udział w badaniu. Pomiary wykonano w Ośrodku Kształcenia Podyplomowego Pielęgniarek i Położnych w Rzeszowie oraz w Przyrodniczo-Medycznym Centrum Badań Innowacyjnych Uniwersytetu Rzeszowskiego.

Badaniami objęto grupę 51 pielęgniarek posiadających prawo wykonywania zawodu. Dobór próby był celowy. Przyjęto następujące kryteria włączenia do badań: dobrowolna zgoda na udział w badaniu, stan zdrowia umożliwiający przeprowadzenie badań z zastosowaniem wybranych narzędzi badawczych, posiadanie kursu specjalistycznego RKO, posiadanie szkolenia specjalizacyjnego lub bycie w trakcie takiego szkolenia. Wszystkie pielęgniarki biorące udział w badaniu spełniły kryteria pielęgniarki systemu $[8,9,10]$. Charakterystykę badanej grupy przedstawiono w tabeli 1.

\begin{tabular}{|c|c|}
\hline & Badana grupa $(n=51)$ \\
\hline & N (częstość) \\
\hline \multicolumn{2}{|l|}{ Wiek } \\
\hline 25 -30 lat & 23 \\
\hline $31-40$ lat & 12 \\
\hline Powyżej 40 lat & 16 \\
\hline \multicolumn{2}{|l|}{ Staż pracy } \\
\hline do 5 lat & 21 \\
\hline 6-10 lat & 13 \\
\hline $11-20$ lat & 8 \\
\hline Powyżej 20 lat & 9 \\
\hline \multicolumn{2}{|l|}{ Wykształcenie } \\
\hline średnie & 10 \\
\hline wyższe & 41 \\
\hline \multicolumn{2}{|l|}{ Specjalizacja } \\
\hline chirurgiczna & 2 \\
\hline kardiologiczna & 2 \\
\hline w trakcie anestezjologicznej & 16 \\
\hline w tracie ratunkowej & 31 \\
\hline
\end{tabular}

Przed badaniami przeprowadzono krótkie, wstępne szkolenie z zakresu obsługi trenażera ewaluacyjnego (głowa do inwazyjnego udrażniania dróg oddechowych - BT-CSIE, BT Inc, 2015). Po wprowadzeniu przedstawiono zadanie, którego celem było założenie rurki krtaniowej (LT-D, rozmiar 5, VBM Laryngeal Tube) oraz maski krtaniowej silikonowej (LMA, rozmiar 5, Zarys), zgodnie z posiadaną wiedzą oraz umiejętnościami. Kolejność zakładania LT-D i LMA odbywała się w sposób niezależny. Następnie pielęgniarki prowadziły minutową wentylację za pomocą worka samorozprężalnego (pojemność ok. $1700 \mathrm{ml}$, Ambu, Poland). Za normę prawidłowej objętości oddechowej przyjęto 500-600 ml. Za wyznacznik początku czasu wykonywania zadania przyjęto prawidłowe odchylenie głowy, natomiast końca uszczelnienie LMA lub LT-D oraz wykonanie pierwszego oddechu podczas wentylacji. Poprawność wykonywania zadania była analizowana przy pomocy dedykowanej check-listy. Każda z badanych pielęgniarek bezpośrednio po wykonaniu próby założenia LMA wykonywała próbę założenia LT-D. W przypadku braku poprawności założenia alternatywy w 1 próbie, badane osoby miały możliwość ponownej próby założenia. 
Uzyskane wyniki zostały przeanalizowane za pomocą testów oceniających różnice pomiędzy badanymi grupami. Ze względu na obecność zmiennej zależnej na skali ilościowej, zmiennej niezależnej na skali jakościowej, a także brak normalności rozkładu (oceniono testem Shapiro-Wilka) wykorzystano nieparametryczne analizy: test U Manna-Whitneya (dla 2 prób) oraz test Kruskala Wallisa (dla więcej niż 2 prób). W pracy przyjęto poziom istotności statystycznej $\mathrm{p}<0,05$. Obliczenia przeprowadzono za pomocą pakietu IBMSPSS Statistics 20.

\section{WYNIKI}

Porównując uzyskane wyniki wybranych parametrów dotyczących procedury założenia LMA, stwierdzono wyższą skuteczność maski LMA w stosunku do LT-D w pierwszej próbie. Czas założenia LMA wynosił średnio 30,22 s. (SD 10,44), natomiast LT-D 32,26 s (SD 9,44). Analiza wentylacji wykonywanej przez badane pielęgniarki wykazała wyższą objętość oddechową po udrożnieniu dróg oddechowych maską LMA - średnia 547,84 ml (SD 117,9) w stosunku do wentylacji z użyciem LT-D, którą wykonało 43 pielęgniarki - średnia 522,63 ml (SD 96,58). Średni maksymalny nacisk na siekacze podczas zakładania LMA wyniósł 6,82 $\pm 8,148 \mathrm{~N}$ i wahał się od $0 \mathrm{~N}$ do $16 \mathrm{~N}$, w przypadku LT-D średni maksymalny nacisk wyniósł $4,12 \pm 5,48 \mathrm{~N}$ i wahał się od $0 \mathrm{~N}$ do $16 \mathrm{~N}$.

Stopień odchylenia głowy podczas zakładania LMA wyniósł $59,10 \pm 13,503$ i wahał się od 5 stopni do 69 stopni. W przypadku LT-D większość badanych osób udrażniała drogi oddechowe poprzez odchylenie głowy do tyłu, gdzie średnia wyniosła 61,00 \pm 9,04 i wahała się od 0 stopni do 70 stopni. Ilość wentylacji w ciągu minuty po założeniu LMA wyniósł $16,51 \pm 5,471$ i wahał się od 11 do 31 . Z kolei LT-D średnia ilość wentylacji w ciągu minuty wyniosła $15,20 \pm 4,712$ i wahała się od 4 do 27 . Nie zaobserwowano statystycznie istotnych różnic pomiędzy badanymi metodami (Tab.2).

- Tab. 2. Porównanie założenia LMA i LT-D podczas pierwszej próby

\begin{tabular}{|l|c|c|c|}
\hline \multirow{2}{*}{ Parametr } & \multicolumn{2}{|c|}{ Badana grupa } & \multirow{2}{*}{ p value } \\
\cline { 2 - 3 } & LMA (I próba) & LT-D (I próba) & \\
\hline Czas (s) & $30,22 \pm 10,44$ & $32,36 \pm 9,44$ & 0,457 \\
\hline Nacisk (N) & $6,82 \pm 8,15$ & $4,12 \pm 5,48$ & 0,080 \\
\hline Odchylenie głowy & $59,10 \pm 13,50$ & $61,00 \pm 9,04$ & 0,942 \\
\hline $\begin{array}{l}\text { Objętość } \\
\text { oddechowa (ml) }\end{array}$ & $547,84 \pm 117,90$ & $522,63 \pm 96,58$ & 0,175 \\
\hline Wentylacja & $16,51 \pm 5,47$ & $15,20 \pm 4,71$ & 0,366 \\
\hline
\end{tabular}

test U Manna Whitneya; Czas - czas założenia alternatywy mierzony w sekundach ;

Nacisk - maksymalny nacisk na siekacze mierzony w N; Odchylenie głowy - stopień odchylenia głowy w osi; Objętość oddechowa-średnia objętość oddechowa oddechów zastępczych w ciągu minuty mierzonych w millitrach; Wentylacja - ilość wentylacji w ciągu minuty

Wybrane zmienne takie jak: wiek, staż pracy, poziom wykształcenia, rodzaj posiadanej specjalizacji istotnie nie różnicowały wykonania procedury założenia LMA i LT-D $(\mathrm{p}<0,05)$.

\section{DYSKUSJA}

W przeprowadzonym badaniu oceniono skuteczność alternatywnego udrażniania dróg oddechowych z użyciem maski krtaniowej oraz rurki krtaniowej w warunkach symulowanych, wykonywanego przez pielęgniarki systemu. Oceniono parametry decydujące o skuteczności procedury w odniesieniu do wybranych zmiennych. W badaniach własnych wykazano skuteczność LMA jako narzędzia służącego do udrażniania dróg oddechowych. W pierwszej próbie maska krtaniowa została założona przez wszystkie badane pielęgniarki, natomiast $64,7 \%$ badanych wykonało zadanie poprawnie. Powyższe wyniki są zgodne z obserwacjami innych autorów. W badaniach Van Zundert i wsp. [11], anestezjolodzy zakładali wybrane alternatywy podczas zabiegów operacyjnych na grupie 150 pacjentów. Skuteczność wykonywanej procedury zakładania LMA stwierdzono na poziomie 98-99\% [11]. Ockner i wsp. [12] badając grupę 50 pacjentów poddawanych znieczuleniu, którym zespół anestezjologiczny losowo zakładał LT-D oraz LMA, uzyskał wyniki określające skuteczność maski krtaniowej na poziomie 71-90\% [12].

Według wytycznych ERC zarówno intubacja, jak i udrażnianie dróg oddechowych przy pomocy LMA oraz LT-D powinny być wykonane do 30 sekund [13]. $\mathrm{W}$ badaniach własnych, średni czas założenia wyniósł kolejno 30,22 s dla LMA oraz 32,36 s dla LT-D. Badania Matterlein i wsp. [15] przeprowadzone w grupie 22 anestezjologów, wykazały że wszystkie próby założenia LMA były pomyślne, a czas wykonania procedury mieścił się w przedziale 13-17 s [14,15]. Wentylacja po założeniu LMA okazała się wyższa w stosunku do LT-D, aż 47,1\% badanych wentylowało $\mathrm{z}$ objętością mieszczącą się w granicach 500-600 ml, a średnia ilość wprowadzonych oddechów w czasie 60 s wyniosła średnio 15/minutę.

Rurka krtaniowa LT, podobnie jak LMA stanowi narzędzie do alternatywnego udrażniania dróg oddechowych. W badaniach własnych wentylacja z użyciem LT-D była skuteczna w 60\%. Z kolei w badaniach Ketta i wsp. [16] u pacjentów z NZK, wentylacja z użyciem LT była skuteczna w $80 \%$ przypadków [16].

W badaniach własnych rurkę krtaniową w I próbie założyło 43 badane osoby. Czas wykonania procedury w I próbie mieścił się w granicach 14-59 s, natomiast w II próbie $14-35$ s. Aż $43,1 \%$ badanych po założeniu LT wentylowało w zakresie 500-600 ml, natomiast średnia ilość wykonanych oddechów wyniosła 14/minutę. Nie znaleziono badań innych autorów, odnoszących się do jakości wentylacji z wykorzystaniem LT.

Porównując skuteczność wykorzystania LMA oraz LT-D w badaniach autorskich nie odnotowano istotności statystycznej. Niemniej jednak, udrażnianie dróg oddechowych za pomocą LMA, umożliwiło osiągnięcie wyższej objętości oddechowej przy jednocześnie wyższych wartościach nacisku na siekacze.

Liczne doniesienia wskazują, że najwłaściwszą metodą udrażniania dróg oddechowych jest intubacja dotchawicza. Niemniej wiąże się ona $\mathrm{z}$ wieloma powikłaniami i powinna być wykonywana przez wyszkolony i praktykujący personel medyczny. Osoby, które nie posiadają takich 
umiejętności bądź nie mają możliwości intubacji, powinny zastosować alternatywne metody takie jak LT-D i LMA ze względu na łatwość i szybkość założenia oraz prowadzenia skutecznej wentylacji z użyciem worka samorozprężalnego. Ważne są również systematyczne szkolenia pielęgniarek jak i całego personelu medycznego, w tym możliwość praktycznego wykonywania procedury w stanach nagłego zagrożenia życia.

\section{WNIOSKI}

Skuteczność założenia LMA i LT-D wśród pielęgniarek oceniono na wysokim poziomie, przy jednoczesnym braku istotnych różnic pomiędzy nimi. Wiek, staż pracy, poziom wykształcenia oraz rodzaj posiadanej specjalizacji istotnie nie różnicowały uzyskanych wyników.

\section{ORCID}

Ewelina Iwanicka (iD https://orcid.org/0000-0002-4722-8710

Paweł Więch (iD https://orcid.org/0000-0002-0101-1030

Izabela Sałacińska (D) https://orcid.org/0000-0003-1752-7610

Joanna Przybek-Mita (iD https://orcid.org/0000-0002-8403-5889

\section{REFERENCES/PIŚMIENNICTWO}

1. Josephson ME. Sudden cardiac arrest. Indian. Heart. J. 2014; 66(Suppl 1): 2-3.

2. Perkins GD, Travers AH, Berg RA, et al. Basic life support chapter collaborators. Part 3: Adult basic life support and automated external defibrillation: 2015 international consensus on cardiopulmonary resuscitation and emergency cardiovascular care science. Circulation. 2015; 132(16 Suppl 1): 51-83.

3. Gordon J, Cooper RM, Parotto M. Supraglottic airway devices: indications, contraindications and management. Minerva Anestesiol. 2018; 84(3): 389-397.

4. McNarry AF, Patel A. The evolution of airway management- new concepts and conflicts with traditional practice. Br. J. Anaesth. 2017; 119(1): 154-166.

5. Newel C, Greir S, Soar J. Airway and ventilation management during cardiopulmonary resuscitation and after successful resuscitation. Available online: https://ccforum. biomedcentral.com/articles/10.1186/s13054-018-2121-y (accessed on 22 March 2020).

6. Soar J, Nolan JP, Böttiger BW, et. al. European Resuscitation Council Guidelines for Resuscitation 2015 Section 3. Adult advanced life support. Resuscitation. 2015; 95: 100-147.

7. Wahlen BM, Roewer N, Lange M, et al. Tracheal intubation and alternative airway management devices used by healthcare professionals with different level of preexisting skills: a manikin study. Anaesthesia. 2009; 64(5): 549-554.

8. The Regulation of The Minister of Health of February 28, 2017 concerning the type and scope of preventive, diagnostic, therapeutic and rehabilitation services provided by a nurse or midwife independently without a medical order. Dz.U. 2017 poz. 497. (in Polish). Available online: http://prawo.sejm.gov.pl/isap.nsf/DocDetails. xsp?id=WDU20170000497 (accessed on 28 March 2020).

9. Act of July 15, 2011 on the professions of nurse and midwife. Dz.U. $2011 \mathrm{nr} 174$ poz. 1039. (in Polish). Available online: http://prawo.sejm.gov.pl/isap.nsf/DocDetails. xsp?id=WDU20111741039 (accessed on 28 March 2020).

10. Act of September 8, on the State Emergency Medical Service. Dz.U. $2006 \mathrm{nr} 191$ poz. 1410. (in Polish). Available online: http://prawo.sejm.gov.pl/isap.nsf/DocDetails. xsp?id=WDU20061911410 (accessed on 30 March 2020).

11. Van Zundert TC, Brimacombe JR. Similar oropharyngeal leak pressures during anaesthesia with I-gel, LMA-ProSeal and LMA-Supreme Laryngeal Masks. Acta. Anaesthesiol. Belg. 2012; 63(1): 35-41.

12. Ocker $H$, Wenzel V, Schmucker $P$, et al. A comparison of the laryngeal tube with the laryngeal mask airway during routine surgical procedures. Anesth. Analg. 2002; 95(4): 1094-1097.

13. Polish Resuscitation Council. Resuscitation guidelines. 2015. (in Polish). Available online: https://www.prc.krakow.pl/wytyczne.html (accessed on 2 April 2020).

14. Brimacombe JR. Laryngeal Mask Anesthesia. Principles and Practice. Saunders Elsevier Ltd. London 2004.

15. Metterlein T, Plank C, Sinner B, et al. A comparison of fiberoptical guided tracheal intubation via laryngeal mask and laryngeal tube. SJA. 2015; 9(1): 37-41.

16. Kette F, Reffo I, Giordani $G$, et al. The use of laryngeal tube by nurses in out-ofhospital emergencies: preliminary experience. Resuscitation. 2005; 66(1): 21-25.

Manuscript received/Praca zgłoszona do czasopisma: 29.05.2020

Manuscript accepted/Praca zaakceptowana do druku: 12.11.2020

Translation/Tłumaczenie: Anna Nowak Tłumaczenia, Nauka Języka Angielskiego, Rzeszów 